\title{
ANALISIS FAKTOR-FAKTOR YANG MEMPENGARUHI MINAT PETANI BERUSAHATANI JAGUNG DI DESA MARDINGDING
}

\author{
Nico Ebenezer Ginting ${ }^{1)}$, \& Dionisius Sihombing ${ }^{2{ }^{*}}$ \\ 1) Fakultas Ekonomi, Universitas Negeri Medan \\ 2) Fakultas Ekonomi, Universitas Negeri Medan \\ E-mail : dions1977@gmail.com
}

\begin{abstract}
Abstrak
Penelitian ini bertujuan untuk mengetahui dan memberikan bukti empiris mengenai pengaruh pendidikan, pengalaman, modal terhadap minat petani berusahatani jagung di Desa Mardinding Kecamatan Mardinding Kabupaten Karo. Penelitian ini menggunakan Total Sampling dengan jumlah sampel 54. Data diperoleh dari Kantor Kepala Desa Mardingding. Dengan teknik pengumpulan data menggunakan angket/kuesioner. Kesimpulan dalam penelitian ini bahwa pendapatan, pendidikan, pengalaman, dan modal berpengaruh terhadap minat petani berusahatani jagung di Desa Mardingding.
\end{abstract}

\section{Kata kunci : Pendidikan, Pengalaman, Modal, Minat}

\section{Abstract}

This study aims to find out and provide empirical evidence regarding the effect of education, experience, capital on the interest of corn farmers in Mardinding Village, Mardinding District, Karo Regency. This study uses Total Sampling with a sample size of 54. Data was obtained from the Office of the Village Head of Mardingding. With data collection techniques using questionnaires / questionnaires. The conclusion in this study is that income, education, experience, and capital have an influence on the interest of corn farmers in Mardingding Village.

Key word : Education, Experience, Capital, Interest

\section{PENDAHULUAN}

Dalam sektor agribisnis hortikultura di Indonesia jagung merupakan salah satu produk unggulan dalam sektor ini. Tanaman jagung tidak asing lagi bagi masyarakat Indonesia.

Di Indonesia jagung merupakan komoditas pangan kedua setelah padi, dan sumber kalori atau makanan pengganti beras disamping kalori disamping itu juga sebagai pakan ternak. Kebutuhan akan jagung terus meningkat dari tahun ke tahun sejalan dengan peningkatan taraf hidup ekonomi masyarakat dan kemajuan industri pakan ternak, sehingga perlu upaya untuk peningkatan produksi melalui sumber daya manusia dan sumber daya alam, ketersediaan lahan maupun potensi hasil dan teknologi.

Di Sumatera Utara produsen jagung terbesar berada di Kabupaten Karo lalu diikuti oleh Simalungun dan Langkat. Terlihat pada tabel 1. 
JURNAL PLANS

Penelitian Ilmu Manajemen \& Bisnis

ISSN: $1978-7057$

E-ISSN: 2527-306X

Tabel 1. Lima (5) Besar Daerah Penghasil Produksi Jagung di Provinsi Sumatera Utara 2015

\begin{tabular}{|c|c|c|}
\hline NO & Kabupaten & $\begin{array}{c}\text { Produksi Jagung } \\
\text { (Ton) }\end{array}$ \\
\hline 1 & Karo & 420.199 \\
\hline 2 & Simalungun & 351.538 \\
\hline 3 & Langkat & 150.419 \\
\hline 4 & Dairi & 125.973 \\
\hline 5 & $\begin{array}{c}\text { Deli } \\
\text { Serdang }\end{array}$ & 112.545 \\
\hline
\end{tabular}

Sumber: Dinas Pertanian Sumatera Utara, 2015

Sektor produksi jagung sebenarnya sangat menjajikan, bagi yang ahli dibidang pengolahannya, karna selain sebagai bahan pangan kedua,sektor ini juga bisa jadi produk dengan olahan yang sangat di minati masyarakat umumnya. Mulai dari jagung muda yang bisa di buat sebagai sayur, bisa juga menjadikan jagung bakar, jagung rebus bisa juga ke produk olahan makanan seperti martabak jagung dan bubur jagung serta produk olahan minuman, es jagung. Tapi penurunan produksi jagung dari tahun ke tahun menjadi fenomena saat ini. Terkhusus di Tanah Karo dimana sebagai penyumbang produksi jagung terbesar di Sumatera Utara dapat dilihat dalam tabel 2. berikut;

Tabel 2. Penurunan Produksi Jagung di Kabupaten Karo, Sumatera Utara

\begin{tabular}{|c|c|}
\hline Tahun & Produksi Jagung (Ton) \\
\hline 2012 & 486.283 \\
\hline 2013 & 425.994 \\
\hline 2014 & 413.346 \\
\hline \multicolumn{2}{|c|}{ Sumber:BPS Kabupaten Karo, 2016} \\
\hline
\end{tabular}

Dari tabel diatas dapat dilihat bahwa produksi jagung dari tahun 2012 terus mengalami penurunan. Pada tahun 2013 mengalami penurunan dari produksi jagung tahun 2012 sebesar 60 ton. Dan produksi jagung pada 2014 juga mengalami penurunan 2013 mencapai penurunan sebesar 12 ton.

Tabel 3. Luas Lahan Yang Dibudidayakan di Kecamatan Mardinding

\begin{tabular}{|c|c|}
\hline Tanaman & $\begin{array}{c}\text { Luas lahan yang } \\
\text { dibudidayakan (Hektar) }\end{array}$ \\
\hline Jagung & 14.671 \\
\hline Beras & 3.097 \\
\hline Kemiri & 2.354 \\
\hline Kakao & 635 \\
\hline
\end{tabular}

Sumber: Kantor Kecamatan Mardinding, 2015

Dari pengalaman dan

wawancara yang dilakukan

dilapangan, ada beberapa masalah yang ada di masyarakat dalam mempengaruhi minat petani berusahatani, yakni : pendapatan petani yang kecil, rendahnya pendidikan pendidikan petani, penyuluhan yang kurang dilakukan oleh pemerintah daerah, pengalaman turun menurun masih diterapkan dalam usahatani, luas lahan pertanian berkualitas yang terbatas, dan modal yang kecil dalam menjalankan usaha pertanian.

Penggunaan minat sebagai sebuah aspek kunci terhadap kesesuaian antara seseorang dan pekerjaan, menjadi suatu alasan mengapa para petani usahatani jagung masih tetap bertahan dengan usahatani yang dijalankannya. Menurut Mappiare (dalam Sitty, 2014) bahwa bentuk minat seseorang dipengaruhi oleh latar belakang lingkungan, tingkat ekonomi, status sosial, dan pengalaman.

Petani sebagai kepala rumah tangga berkewajiban memenuhi seluruh tuntutan hidup anggota keluarganya. Mulai pangan, pakaian, pendidikan anak-anak dan biaya kesehatan. Tingkat pendapatan petani yang relatif rendah mengharuskan 
anggota rumah tangga petani untuk lebih giat bekerja.

Dengan pendidikan yang memadai maka pengelolaan dalam hidup dapat terlaksana dengan baik sehingga mengarah kepada kesejahteraan yang baik pula dalam arti lain pendapatan dapat diperoleh dengan baik.

Kecamatan Mardinding di Kabupaten Karo sebagian besar penduduknya bermata pencarian sebagai petani. Namun, penyuluhan dalam pertanian dinilai masih kurang dari pemerintah daerah. Hal ini seharusnya tidak terjadi mengingat sekarang sudah diterapkan otonomi daerah sehingga pemerintah daerah harus fokus terhadap komoditas dihasilkan suatu daerah yang akan menjadi sumber pendapatan daerah.

Pekerjaan dalam usahatani biasanya pekerjaan turun temurun dari orang tua ke anaknya, maka tak heran jika sebagian besar petani memiliki pemahaman yang sama dengan orang tua di ladang. Maka ketika mereka mulai berusahatani secara mandiri pengalaman yang ada cukup untuk mereka mulai bekerja keras.Akan tetapi pngalaman yang ada harus disesuaikan dengan perkembangan teknologi pertanian, agar usaha taninya semakin maju dari pada usaha tani yang pernah dilakukan orang tua mereka.

Walaupun luas, lahan pertanian jika tidak disertai kualitas lahan yang baik pula maka petani mengalami kerugian. Disebakan petani kurang perhitungan terutama dalam pemberian pupuk. Padahal sebenarnya pada lahan yang sempit efesien usaha lebih mudah diterapkan, karena mudahnya pengawasan, penggunaan lahan, dan penerapan cara intensifikasi. Dengan demikian jika usaha pertanian dalam peningkatan produksi akan tercapai, otomatis pendapatan yang memjadi tujuan akhir akan diperoleh.

Setelah luas lahan, modal merupakan salah satu faktor yang sangat penting dalam mendukung produksi pertanian dalam arti sumbangannya pada pendapatan petani. Tersedianya modal yang cukup pada petani untuk memulai usaha membuat petani mempunyai minat dan semangat yang tinggi dalam berusaha tani serta mampu bekerja secara maksimal. Modal memiliki banyak arti yang berhubungan dalam finansial dan akutansi. Dalam finsansial dan akutansi, modal biasanya menunjuk kepada kekayaan finansial, terutama dalam penggunaan awal atau menjaga kelanjutan usaha.

Dari sejumlah faktor yang mempunyai pengaruh terhadap minat para petani di Desa Mardinding dalam berusahatani jagung, yang menjadi perhatian peneliti adalah faktor internal petani itu sendiri, yaitu pendapatan, pendidikan, pengalaman, dan modal mempengaruhi minat petani.

\section{METODE PENELITIAN}

Lokasi penelitian ini
dilakukan di Desa Mardinding, Kecamatan Mardinding, Kabupaten Karo. Menurut Istijanto, (dalam Sudjana 2012: 15) populasi merupakan jumlah keseluruhan yang mencakup semua anggota yang diteliti. Sesuai dengan pengertian tersebut yang menjadi populasi dalam penelitian ini adalah petani jagung yang berada di desa Mardinding, dengan jumlah data yang di peroleh 
dari kantor kepala desa populasi petani sebanyak 54 petani jagung. Penentuan sampel dalam penelitian ini menggunakan Total Sampling. Total Sampling adalah pengambilan sampel dari semua anggota populasi. Sampel dalam penelitian ini berjumlah 54 petani. Untuk mengetahui seberapa besar pengaruh Pendapatan $\left(\mathrm{X}_{1}\right)$, Pendidikan $\left(\mathrm{X}_{2}\right)$, Pengalaman (X3) dan Modal (X4) terhadap minat berusaha tani (Y) maka digunakan rumus metode analisis regresi linier berganda (multiple linier regresion) (Sudjana, 2002).

\section{HASIL DAN PEMBAHASAN Hasil Penelitian}

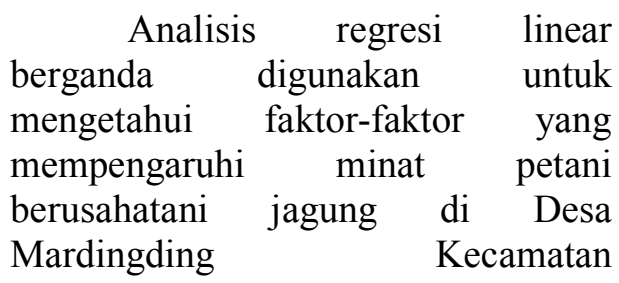
Mardingding Kabupaten Karo. Dari olah data SPSS dijelaskan sebagai berikut:

$Y=9,842+0,456 X_{1}-0,308 X_{2}+0,488 X_{3}+0,240 X_{4}+e$

a. Konstant sebesar 9,842 menyatakan bahwa jika tidak ada variabel $\mathrm{X}$, maka minat petani berusahatani adalah sebesar 9,842

b. Koefisien X1 sebesar 0,456 menyatakan bahwa setiap terjadi peningkatan pendapatan akan mempengaruhi minat petani berusahatani sebesar 0,456

c. Koefisien X2 sebesar-0,308 menyatakan bahwa setiap terjadi peningkatan pendidikan akan mempengaruhi minat petani berusahatani sebesar 0,308 d. Koefisien X3 sebesar 0,488 menyatakan bahwa setiap terjadi peningkatan pengalaman akan mempengaruhi minat petani berusahatani sebesar 0,488

e. Koefisien X4 sebesar 0,240 menyatakan bahwa setiap terjadi peningkatan modal akan mempengaruhi minat petani berusahatani sebesar 0,240

Dari hasil uji hipotesis diperoleh uji $\mathrm{F}$ dengan signifikasi sebesar 90\% menunjukkan Ftabel adalah 2,06 dan hasil pengolahan data mendapatkan Fhitung sebesar 5,146, berarti dapat disimpulakn Fhitung $>$ Ftabel yang mengartikan s bahwa terdapat pengaruh yang signifikan secara simultan antara $\mathrm{X} 1, \mathrm{X} 2, \mathrm{X} 3$, dan X4 terhadap Y.

Selain itu juga pada uji t, penelitian ini juga memenuhi hipotesis yang telah ditentukan. Pada Pendapatan ( X1) thitung sebesar 2,967, pada Pendidikan (X2) $t_{\text {hitung }}$ sebesar 2,204, pada Pengalaman (X3) $t_{\text {hitung }}$ sebesar 2,605, dan pada Modal (X4) $t_{\text {hitung }}$ sebesar 1,964 , sedangkan $t_{\text {tabel }}$ sebesar 1,676. Data data tersebut menunjukkan bahwa $t_{\text {hitung }}>t_{\text {tabel. }}$. Maka hipotesis diterima

Dan hasil pengolahan data untuk koefisien determinasi ( $\mathrm{R}$ Square) menunjukkan angka sebesar 0,826 mengindikasikan bahwa sebesar $82,6 \%$ perubahan dalam minat petani berusahatani dapat dijelaskan oleh variabel pendapatan, pendidikan, pengalaman dan modal. Sedangkan sisanya $17,4 \%$ di jelaskan oleh variabel lain diluar penelitian.

\section{Pembahasan}

Maka dapat disimpulkan benar adanya minat merupakan suatu motif 
yang menyebabkan individu berhubungan secara aktif dengan obyek yang menarik baginya.oleh karena itu, minat dikatakan sebagai suatu dorongan untuk berhubungan dengan lingkungannya, kecenderungan untuk memeriksa, menyelidiki atau mengerjakan aktivitas yang menarik baginya. Apabila individu menaruh minat terhadap sesuatu hal maka obyek itu berguna untuk memenuhi kebutuhannya. (Woodworth dan Marquis (Moekijat, 2001 : 8)) Dari keseluruhan hasil penelitian ini menunjukkan bahwa pendapatan pendidikan, pengalaman dan modal mempunyai pengaruh terhadap minat petani berusahatani Di Desa Mardingding, Kecamatan Mardingding, Kabupaten Karo.

\section{SIMPULAN}

Hasil penelitian terbukti bahwa variabel pendapatan berpengaruh terhadap minat petani berusahatani jagung di Desa Mardingding Kecamatan Mardinding Kabupaten Karo, variabel pengalaman berpengaruh terhadap minat petani berusahatani jagung di Desa
Mardingding Kecamatan Mardinding Kabupaten Karo, variabel modal berpengaruh terhadap minat petani berusahatani jagung di Desa Mardingding Kecamatan Mardinding Kabupaten Karo. Dan secara bersama-sama variabel pendapatan, pendidikan, pengalaman, dan modal berpengaruh terhadap minat petani berusahatani jagung di Desa Mardingding Kecamatan Mardinding Kabupaten Karo.

\section{DAFTAR PUSTAKA}

Badan Pusat Statistik Indonesia, 2015. (BPS.go.id)

Dinas Pertanian Sumatera Utara, 2015

Kantor Kecamatan Mardinding, 2015

Moekijat.2002. Manajemen Sumber Daya Manusia, Mandar Maju: Bandung

Sitty, 2014. "Faktor-Faktor Yang Mempengaruhi Minat Petani Berusahatani Padi Di Desa Sendangan Kecamatan Kakas Kabupaten Minahasa” Universitas Sam Ratulangi Manado. Skripsi. Tidak Dipublikasikan

Sudjana. 2002. Metode Statistika. Bandung: Tarsito 